\title{
Misty consensus, messy dissensus: paradoxes of the Brazilian innovation policies
}

\author{
Luiz Ricardo Cavalcante
}

Brazilian Federal Senate, Brasilia, Brazil and

Instituto Brasiliense de Direito Publico, Brazil

\begin{abstract}
Purpose - The purpose of this paper is to show that the wide acknowledgement of the association between innovation and economic and social development and of the importance of innovation policies has formed a kind of "misty consensus" hardly contested in Brazil. However, the innovation policies adopted in the country lack an institutional framework to support their implementation, marking what is called in this paper a "messy dissensus".
\end{abstract}

Design/methodology/approach - It is argued that the reasons why the science, technology and innovation (ST\&I) policies have failed to contribute more effectively increasing Brazilian technological efforts have less to do with the policies themselves and more to do with their detachment from the institutional framework used to implement them.

Findings - It is shown that this institutional framework: (i) is barely adherent to the perception of the systemic nature of the innovation process; (ii) does not create enough incentives for bureaucrats in public institutions to allocate resources in the industrial sector; (iii) encourages the pulverization of resources and the consequent loss of focus, which may reduce the efficiency of the adopted policies; (iv) encourages the replication of models and priorities usually adopted in contexts that fail to match the Brazilian reality.

Originality/value - In this paper, the focus is on the obstacles that undermine the potential of ST\&I policies to contribute more effectively to the improvement of the Brazilian innovation indicators. It is argued that these obstacles have less to do with the innovation policies themselves and more to do with their detachment from the institutional framework used to implement them. This institutional framework includes not only the formal and legal rules but also informal social norms that govern individual behavior and structure social interactions.

Keyword Innovation policies

Paper type Research paper

\section{Introduction}

The wide acknowledgement of the association between innovation and economic and social development has been motivating a growing presence of this subject in the public policies worldwide agenda during recent decades. Unlike the macroeconomic prescriptions - which are frequently subject to irreconcilable divergences - innovation policies form a kind of "misty consensus", as antagonists to their adoption are hardly found. In fact, innovation policies have been considered very important not only by politicians and bureaucrats but

(C) Luiz Ricardo Cavalcante. Published in Innovation \& Management Review. Published by Emerald Publishing Limited. This article is published under the Creative Commons Attribution (CC BY 4.0) licence. Anyone may reproduce, distribute, translate and create derivative works of this article (for both commercial and non-commercial purposes), subject to full attribution to the original publication and authors. The full terms of this licence may be seen at http://creativecommons.org/licences/by/4.0/legalcode

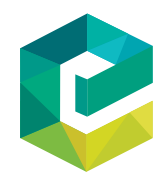


INMR 15,4

also by society as a whole, including, obviously, academic communities and business associations. Furthermore, conflicts usually observed between employers and employees are hardly observed in this case.

In Brazil, since the 1990s, the recurrent comparisons between the local economy and the fast growing Asian ones - especially South Korea - led to the crystallization of the perception that it would be necessary to provide more incentives for innovation in the industrial sector. That kind of perception relied on the fact that Brazil had managed to catch up in scientific production but failed to increase its technological production significantly. This essentially consensual perception led to the adoption, since the 1990s, of innovation policies explicitly focused on the industrial sector[1].

The spread of innovation policies focused on the industrial sector and the relatively high rates of growth of the gross domestic product (GDP) in the period before 2014 contributed to create an expectation that a leap in the innovation indicators would show up in the results of the last edition of the Brazilian Innovation Survey (PINTEC)[2]. Issued by the Brazilian Institute of Geography and Statistics (IBGE) according to the Organization for Economic Co-operation and Development (OECD, 2005) guidelines, the last edition of the survey covers the period between 2012 and 2014. However, as shown in Section 2 of this work, in spite of some advances, results somehow frustrated the expectations. When compared to a set of selected countries used as reference, the relatively poor results obtained in Brazil suggest some kind of "red queen race", which refers to a quotation extracted from Lewis Carroll's Through the Looking-Glass[3]. Obviously, public policies are not the only factor that explains the behavior of innovation indicators. In the Brazilian case, in addition to the policies, there is evidence that the relatively low technological efforts of the industrial sector are associated to the following structural and systemic factors:

- The local industrial structure, which is relatively less concentrated in high tech sectors than the ones in more developed countries. Feldmann (2009, p. 136) shows that "even the big Latin American companies do not belong, in general, to high technology sectors"[4].

- The higher share of multinational firms in high tech industries in Brazil, as these firms tend to concentrate their technological efforts in their countries of origin (De Negri, 2012).

- The high levels of capital cost in Brazil, which makes innovation investments less attractive to the industrial sector when their risks are taken into account[5].

- The relatively low exposure of the Brazilian firms to international competition[6].

Given their structural and systemic nature, these factors do not change abruptly. However, the spread of the innovation policies focused on the industrial sector and the positive economic environment created the expectation of an improvement in the indicators which in fact did not happen. In this work, however, the focus is on the obstacles that undermine the potential of science, technology and innovation (ST\&I) policies to contribute more effectively to the improvement of the Brazilian innovation indicators[7]. It is argued that these obstacles have less to do with the innovation policies themselves and more to do with their detachment from the institutional framework used to implement them. This institutional framework includes not only the formal and legal rules but also informal social norms that govern individual behavior and structure social interactions. The basic argument of this work - which is detailed in Section 3 - is that a "messy dissensus" creates institutional obstacles to the full effectiveness of consensual innovation policies[8]. To support this proposition, a set of data and arguments are systematized in this paper. 

industrial sector. The adoption of those policies was concurrent with the emergence of the national innovation system concept in the theoretical field. The concept originally proposed by Freeman (1987) and Lundvall (1988) includes, in its broad perspective, several subsystems which are interconnected and influenced by the geopolitical, cultural, social, political, economic and local contexts. Thus, as stressed by Cassiolato and Lastres (2008), a more complete view of the national innovation system is not limited to a narrow perspective which would associate it only to the production/innovation and the capacity-building, research and technological services subsystems. In fact, the national innovation systems have increasingly recognized typically institutional aspects which involve, for example, rules, norms and incentives. This perception explains why this work adopts a broad perspective of the national innovation systems. Cassiolato and Lastres (2008) argue that since the early 1990s, the concept of national innovation system "has been used as an analytical tool and as a framework for policy analysis in both developed and underdeveloped countries". That is essentially the context in which the so-called systemic model of innovation - which adopts a more broad and complex conception of the innovation phenomenon - spread among policy-makers.

As it considers the simultaneous influence of organizational, institutional and economic factors on the processes of generation, diffusion and adoption of ST\&I, the systemic model is broader than the linear one, which, according to its stylized description, assumes that innovation results from sequential steps from basic research to applied research and then to development, production and marketing[9]. The policy implication of the linear model is, then, to create a public research infrastructure, as the firms would in a more or less spontaneous way benefit from the results of the activities performed in universities and research centers[10]. A systemic approach, on the other hand, emphasizes interactions as a key condition to promote innovation in individual companies. As stressed by Johannessen (2009), the policy implication of the interactive model is that the emphasis on research must turn more towards relations among elements generating innovation systems at various system levels.

Given the complex nature of the innovation process, a systemic approach seems to be more realistic than a stylized model like the linear one. However, while the linear model is, at the same time, analytical (because it proposes a model that permits an interpretation of the reality) and prescriptive (because policy implications emerge from it immediately), the systemic model is predominantly analytical and less prescriptive. The less prescriptive nature of the systemic model explains why it is harder to extract concrete innovation policy instruments from it. Lundvall and Borrás (2005, p. 615), for instance, propose a framework where they report, in sequence, policy instruments aimed at science, at technology and at innovation. Those instruments form a kind of sequence of layers, as the technology policies include the science policies and the innovation policies include the technology policies. However, in the case of the innovation policies, the reported instruments seem more related to a "wish list" than to concrete actions which could be immediately implemented. This is the case, for example, of actions like improving the access to the information society or improving the social capital for regional development. On the other hand, the instruments associated to the science and technology policies - such as public funding of research activities, creation of public research centers or public procurement - seem much more directly applicable.

In Brazil, the spreading of the systemic model since the 1990s was concurrent with the adoption of several innovation policies focused on the industrial sector. Thus, in 1993, Law 
INMR

15,4

n. 8.661/1993 was enacted to establish the conditions for the concession of fiscal incentives for the technological capacitation of the agricultural and industrial sectors. In spite of the reduced number of firms that benefited from that law (largely because of the rigid and bureaucratic procedures to access the fiscal incentives), it might be considered a turning point in the Brazilian ST\&I policies as it explicitly focuses on the industrial sector. In the late 1990s, the so-called Brazilian science and technology sector-specific funds were established aiming at providing more stable financial resources to ST\&I activities and at increasing the total amount directed to $R \& D$ activities in the industrial sector. Those funds aimed at creating an institutional environment that was more favorable to the deepening of the cooperation between public agents and the industrial sector (Morais, 2009, p. 67). The enactment of the so-called Innovation Law in 2004 (Law n. 10.973/2004) aimed to create instruments to regulate the relationship between universities and research centers, on one hand, and the industrial sector, on the other hand. Besides, the Innovation Law created the legal background for the allocation, by the Brazilian Innovation Agency (FINEP) of grants to business enterprises, which were, until then, forbidden (or at least controversial) in Brazil. The following year, the legal framework to provide fiscal incentives to R\&D activities in Brazil was improved, as those incentives were included in the third chapter of the so-called "Lei do Bem" (Law n. 11.196/2005). Since the mid-2000s, the FINEP launched several public programs and calls to support business enterprises and, in the late 2000s, Law n. 12.349/2010 created the legal framework for the use of public procurement as an instrument for supporting innovation efforts made by business enterprises. Finally, the Constitutional Amendment n. 85/2015 altered several constitutional provisions to improve the articulation between the state and the public and private research institutions and to broaden the set of institutions eligible for public support for research. Given all those movements, the Brazilian innovation policies may be considered modern and similar to the ones adopted in more developed countries. Besides, there is considerable evidence that those instruments have positive and significant impacts on the technological efforts firms make. Araújo et al. (2012), for example, used sophisticated statistical methods to control for the selection bias typically observed in the analysis of innovation policies and concluded that the access to the sectorspecific funds has positive and significant impacts on the firms' $R \& D$ expenditures.

However, the advances observed in the legal framework were not fully reflected in the increasing of the technological efforts of the industrial sector in the country. In fact, between 2000 and 2015, and in spite of the peak in the mid 2010s, business enterprise R\&D expenditures (taken as a proxy of the technological efforts of the industrial sector) in Brazil remained fairly stable, as shown in Figure 1.

The data used to plot Figure 1 were calculated on the basis of the Brazilian innovation surveys, which are performed every three years. For the remaining years, the Ministry of Science, Technology, Innovation and Communications (MCTIC is the acronym in Portuguese) and the former Ministry of Science, Technology and Innovation (MCTI is the acronym in Portuguese) either interpolated the business enterprise R\&D expenditures or extrapolated them for the years after the last available one[11]. Even when those caveats are considered, the fact is that no significant increase of the ratio between the business enterprise R\&D expenditures and the GDP was observed in Brazil during the period shown in the figure. In particular, when the period between 2005 and 2013 is considered (as a reference to comparisons with other countries shown in Table I), there was a small decrease in the ratio (from 0.52 to 0.51 per cent or 0.01 percentage point).

The Brazilian numbers strongly contrast with the increase of the business enterprise R\&D investments in the set of selected countries shown in Table I. 


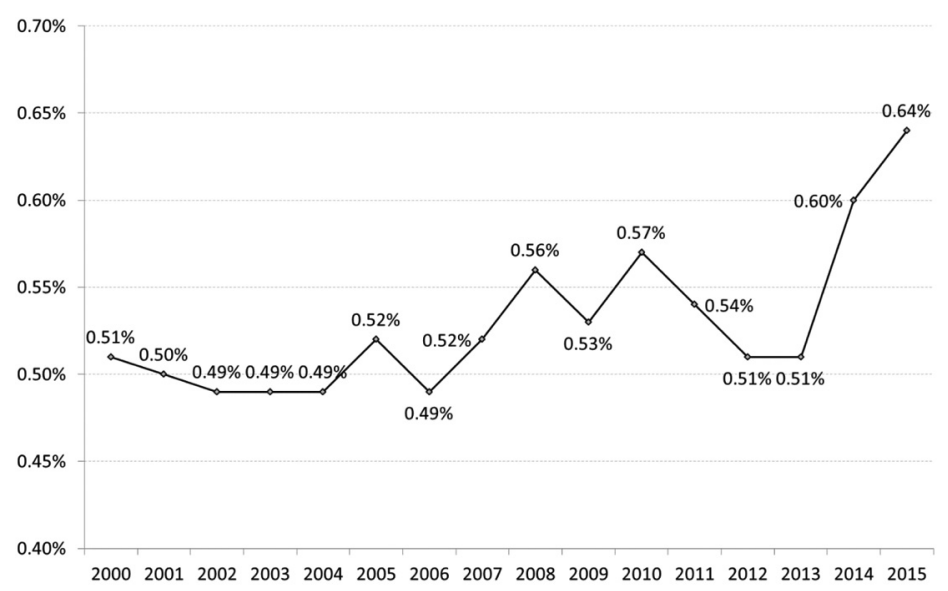

Source: Elaborated by the author based on MCTIC data available at: https://goo.gl/VmhyUW

\section{Misty consensus, messy dissensus \\ Figure 1. Business enterprise R\&D expenditures/ GDP, Brazil, $2000-2015$}

\begin{tabular}{lccc}
\hline Country & 2005 (per cent) & 2013 (per cent) & Variation (p.p.) \\
\hline Brazil & 0.52 & 0.51 & -0.01 \\
United States & 1.73 & 1.92 & 0.19 \\
European Union (19 countries) & 1.12 & 1.34 & 0.22 \\
European Union (28 countries) & 1.10 & 1.29 & 0.19 \\
Portugal & 0.29 & 0.63 & 0.34 \\
Spain & 0.59 & 0.67 & 0.08 \\
South Korea & 2.02 & 3.26 & 1.24 \\
China & 0.90 & 1.54 & 0.64
\end{tabular}

Source: Elaborated by the author based on Eurostat data available at: https://goo.g1/HoiQNw

\section{Table I.}

Business enterprise R\&D expenditures/ GDP, selected countries and groups (2005 and 2013)

As shown above, there was a generalized growth of the ratio between business enterprise R\&D expenditures and GDP, as all the countries or groups of countries in Table I (except for Brazil) had positive variations in that indicator. In the case of the USA (a large country with relatively high business enterprise R\&D expenditures and a diversified economy), there was an increase of almost 0.20 percentage points. A similar variation can be observed in the case of the European Union, where R\&D investments are smaller than the ones in the USA. Countries traditionally marked by lower business enterprise $R \& D$ expenditures and where institutions are more similar to the ones in Brazil (Portugal and Spain) also increased their indicators between 2005 and 2013. In the case of South Korea, the higher level of business enterprise R\&D expenditures in 2005 did not prevent an increase of 1.24 percentage points. The numbers regarding the USA, the European Union and South Korea show that even countries located on the technological frontier managed to increase their ratio between business enterprise R\&D expenditures and GDP. Finally, in the case of China, a clear catch up process took place, as the aggregation of modern sectors to the local economy has been contributing to a significant increase in the local business enterprise R\&D expenditures. In short, Table I clearly confirms the "red queen race" mentioned in the introduction of this paper. 
INMR

15,4

\section{The dissensus: the institutional obstacles}

As shown in the previous section, the slow evolution of the Brazilian innovation indicators in a context marked by the spreading of innovation policies focused on the industrial sector and by reasonably high GDP growth rates (before 2014) suggests the existence of some kind of paradox, especially if the Brazilian data are confronted with the ones of other countries in the same period. Although innovation policies are far from being capable of explaining by themselves the path followed by the national ST\&I indicators, this section discusses the obstacles that limit the potential of those policies to contribute more effectively to the improvement of the Brazilian innovation indicators. The basic underlying hypothesis is that these obstacles have less to do with the innovation policies themselves and more to do with their detachment from the institutional framework used to implement them. This detachment becomes more evident in the four aspects discussed in the subsections below.

\subsection{Difficulties in implementing the systemic model}

The first aspect of the detachment of the innovation policies from the institutional framework used to implement them has to do with the conceptual basis on which those policies rely. Although formulated according to a systemic model of the innovation process, the policies strongly rely on instruments that have much more to do with the linear model. As shown in Section 2, the linear model is more prescriptive than the systemic one, as the focus of the policies is placed on the scientific production, which would spin off to the industrial sector. Obviously, this kind of prescription is barely applicable to policies formulated considering the systemic model of innovation (Cavalcante, 2009). In spite of that, the instruments used in the "systemic policies" are essentially the same as those used in the "linear policies". That is the case, for example, of the grants directed to researchers, which remain strongly based on the scientific production (papers published) and only marginally consider the technological production (patents, for example) of the candidate.

This kind of incentive obviously helps to explain the divergence of the Brazilian scientific and technological indicators. In fact, the Brazilian share in the number of scientific papers indexed by the Scopus - which may be considered a proxy for the scientific production grew from 1.18 per cent, in 2000 to 2.57 per cent in 2015 (Figure 2).

Although the share in 2015 was still low as compared to countries like the USA (22.26 per cent) and even some BRICS countries (Russian Federation, 2.59 per cent; India, 5.11 per cent; China, 17.83 per cent; South Africa, 0.72 per cent), it is quite clear that there has been a significant increase in the Brazilian scientific production over the past 15 years.

On the other hand, the country's share in the world patents granted by the US Patent and Trademark Office (USPTO) - which, in spite of its traditional methodological limitations may be considered a proxy for the technological production - was restricted to around 0.1 per cent in the mid-2010s (Figure 3).

There seems to have been an increase since 2011 (from 0.06 to 0.11 per cent). However, in 2015 , the number of patents granted to Brazilian residents reached 323, while some BRIC countries reached thousands (Russian Federation, 440; India, 3,355; China, 8,116; South Africa, 166). A look at USPTO data shows that Brazil has never gone beyond 400 patents per year.

The difficulties to put action into effect under the systemic view of the innovation process are confirmed by anecdotal, thought recurrent and hardly deniable, evidence. De Negri et al. (2009), for instance, show that only 1,831 (13.6 per cent) out of 13,433 projects supported by the sector-specific funds involve firms. Although those cooperative projects represent around 35 per cent of the total resources, the concentration of the resources in universities is quite evident. Accordingly, Kubota et al. (2012) show that the so-called CT-Info 


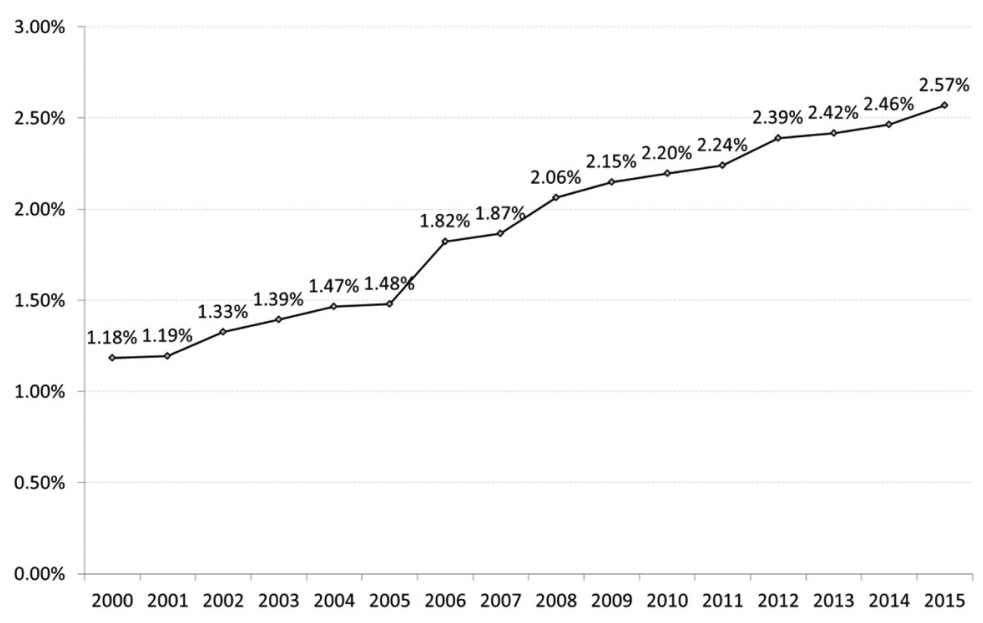

Source: Elaborated by the author based on MCTIC data available at: https://goo.gl/vWhse2

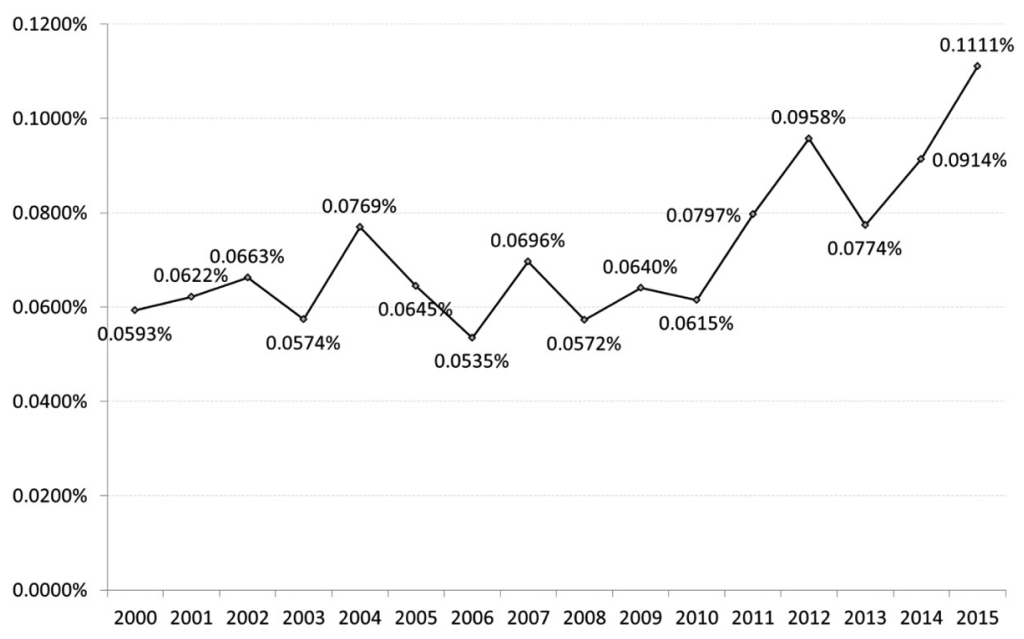

Source: Elaborated by the author based on USPTO data available at: https://goo.gl/vWhse2
Figure 3. Brazilian share in the world patents granted by the United

States Patent and

Trademark Office (USPTO)

(a sector-specific fund aimed at the information and telecommunication technologies) supported only 99 firms in the period between 2002 and 2007. This kind of result led the authors to suggest that the fund had been captured by what they call "the academy complex". All the data reinforces the perception that the industrial sector still has only limited access to public resources for ST\&I in Brazil. These difficulties are also explained by the proportionally larger emphasis the Brazilian support agencies put on scientific production as compared to technological production. In fact, the criteria the agencies such as 
INMR

15,4

the National Council for Scientific and Technological Development (CNPq) and the Coordination for the Improvement of Higher Level Personnel (CAPES) use to select projects create incentives to publish papers, but not to deposit patents, for example (De Negri and Cavalcante, 2013).

In spite of this more general framework, there are some successful cases marked by high interaction levels between universities, research centers and firms. The successful cases of aircraft technologies, agriculture innovation and offshore oil extraction observed in Brazil seem to reinforce this perception. In fact, the research networks around Embraer, Embrapa and Petrobras have been achieving significant outputs. Formerly a public company, Embraer has become one of the world's two leading producers of regional jet passenger aircraft. The Brazilian Agricultural Research Corporation (Embrapa) is a public company which provides solutions for the development of Brazilian agribusiness through technology generation and transfer. Finally, Petrobras, one of the largest oil companies in the world, is controlled by the Brazilian federal government and is a world leader in offshore oil exploitation technology. All those cases are path dependent and have been marked by a long-term involvement of both government and industry and some sort of institutional network. As a result, they are not easily replicable in other contexts.

\subsection{Low incentives to direct resources to the industrial sector}

In spite of the misty consensus about the necessity of directing resources to R\&D activities in the industrial sector in Brazil, it is much more socially accepted that the government should direct its resources to universities and public research centers. In fact, before the enactment of the "Innovation Law", it was forbidden - or, at least, legally controversial - to direct grants to R\&D projects carried out by firms. In general, bureaucrats responsible for the allocation of this kind of resource are afraid of being accused of favoring firms in exchange for any kind of benefit. As their salaries and their possibilities of getting a promotion are not directly associated to the effectiveness of the innovation policies focused on the industrial sector, bureaucrats would rather direct resources to more socially accepted projects in nonprofit organizations. This seems to be valid even when there are good projects and firms are capable of implementing them.

This is Viotti's (2008, p. 161, translated by the author) point of view, to whom:

Be it because of their own nature, be it because of the traditional and institutionalized practices, public agencies may find it easier to deal with and support universities and research centers, but they find it very hard to do something similar when firms are involved. This difficulty has especially to do with the efforts to implement the new instruments of the policies which are aimed at innovation, as in the case of grants and of public procurement of new products and processes.

Accordingly, public development banks, which for decades provided credit to the industrial sector in Brazil, have difficulties in allocating resources to innovation activities, as it is harder to estimate future cash flows and these projects usually have less collateral than more traditional ones. As a result, development banks have fewer incentives to direct their resources to innovation projects. Even in the case of the Brazilian Innovation Agency (FINEP), which focuses on innovation projects, there might be cases where credit operations are troubled by the projects higher risk levels.

Although this aspect lacks objective evidence (bureaucrats would hardly explicitly recognize that their decisions may not be the best for their institutions), there seems to be a rationale for it. Risk aversion of bureaucrats - whose wages and possibilities of getting a promotion are not related to their focus on innovation - seems to be the underlying reason for this behavior. 


\subsection{Pulverization of resources}

Another aspect of the detachment of the innovation policies from the institutional framework used to implement them are the obstacles to establishing priorities for these policies. In general, bureaucrats responsible for the allocation of resources to financing innovation activities have more incentives to pulverize the resources over a large number of small projects than to concentrate them in a smaller, but more coherent, number of projects. That is essentially a consequence of the way the bureaucrats are legitimized. As bureaucrats rely on the approval of the "scientific community", they prefer to contemplate each researcher with a small amount of resources instead of allocating them to a smaller number of larger projects. In short, they prefer to have "twenty little friends" and not "nineteen little enemies and one big friend". As a result, innovation policies tend to be shaped by the demand and not by the focus on strategic areas and the projects tend to lack scale and continuity.

According to data presented by De Negri et al. (2009), the average value of the projects financed by the sector-specific funds between 2000 and 2008 was US $\$ 140$ thousand. Although it might be considered relatively high in some more traditional sectors marked by incremental innovations, it is unlikely that this amount is enough to carry out competitive projects in areas like biotechnology and nanotechnology, which tend to require large scale laboratories. Table II, built upon data presented by De Negri et al. (2009), shows the average project value for each sector-specific fund in the period 2000-2008.

As shown in the table, the average project value ranges from US $\$ 52$ thousand, in the case of the water resources fund, to US\$2 million, in the case of the telecommunications fund.

\begin{tabular}{|c|c|c|c|}
\hline & No. of projects & Total value ( $\mathrm{R} \$$ thousand) & $\begin{array}{l}\text { Average value } \\
\text { ( } \mathrm{R} \$ \text { thousand) }\end{array}$ \\
\hline Aeronautics & 47 & 40,975 & 872 \\
\hline Agribusiness & 683 & 37,112 & 54 \\
\hline Amazônia & 78 & 19,077 & 245 \\
\hline Waterborne transport & 57 & 12,149 & 213 \\
\hline Biotechnology & 189 & 22,904 & 121 \\
\hline Energy & 640 & 81,605 & 127 \\
\hline Space technology & 6 & 1,812 & 302 \\
\hline Water resources & 786 & 41,237 & 52 \\
\hline Informatics & 524 & 35,356 & 67 \\
\hline Infrastructure & 811 & 354,264 & 437 \\
\hline Mineral resources & 161 & 12,356 & 77 \\
\hline Oil & 1,228 & 112,272 & 91 \\
\hline Health & 424 & 27,638 & 65 \\
\hline Transport & 9 & 1,678 & 186 \\
\hline Transversal projects & 5,854 & 494,891 & 85 \\
\hline Telecommunications & 54 & 108,218 & 2,004 \\
\hline FNDCT & 707 & 79,288 & 112 \\
\hline Other sources & 242 & 48,824 & 202 \\
\hline Grants & 330 & 281,025 & 852 \\
\hline "Horizontal fund" ("green and yellow") & 603 & 70,725 & 117 \\
\hline Total & 13,433 & $1,883,406$ & 140 \\
\hline
\end{tabular}

Note: Values originally in Brazilian Reals (BRL) converted to US\$ using the average exchange rate of the period 2000-2008

Source: Elaborated by the author based on data by De Negri et al. (2009)

Table II.

Number of projects, total and average value, sector funds, 2000-2008 
INMR

15,4

Even the largest amounts may be considered low when compared with the average size of projects in leading economies. This kind of perception led Morais (2009, p. 37) to argue that "there was a pulverization of resources in a high number of small projects which had low impact on the country's competitiveness".

\subsection{Isomorphic innovation policies}

Even if it was possible to avoid the pulverization of resources, the priorities established for the innovation policies would tend to be generic and to reproduce the priorities of other countries marked by different economic and social realities, leading to a kind of "isomorphism" analogous to the concept originally proposed by Meyer and Rowan (1977). According to those authors, organizations tend to keep their structures isomorphic aiming at legitimacy. This perception is similar to Keynes's (1937, p. 214) proposition that "knowing that our own individual judgment is worthless, we endeavor to fall back on the judgment of the rest of the world which is perhaps better informed".

In the specific case of the innovation policies, the bounded rationality, the bureaucrat's need of legitimacy and the high levels of uncertainty are the reasons why policy-makers tend to replicate models and priorities shaped in other contexts. As bureaucrats responsible for the allocation of resources need to legitimize themselves in the eyes of the politicians, it is reasonable to assume that their decisions are oriented, to some degree, by their desire for acknowledgment. Evidences for this argument may be found in cross-country comparisons of ST\&I priorities in OECD countries (OECD, 2010, p. 89 apud IEDI, 2011). The OECD segments those priorities into groups like "environment, climate change and oceans", "health and life sciences" or "natural resources and energy". Some countries declared more than ten ST\&I priorities, and on several occasions, those priorities seem detached from local conditions or endowments. As a result, priorities established for Turkey, for example, do not seem much different from the ones established for Germany.

In Brazil, explicit industrial and ST\&I policies usually present generic challenges (such as "to promote innovation and technological development") or mention several of the topics used by the OECD to compare ST\&I priorities. For example, the so-called "Plano Brasil Maior" issued in 2011 mentions national security ("complexo industrial da defesa"), sustainability, renewable energy sources, health, social challenges ("social inclusion"), engineering, nanotechnology, biotechnology, information and communication technologies and cultural diversity. In short, almost all priorities used by the OECD are somehow mentioned in the industrial and ST\&I policy issued in 2011 (Brasil, n.d). In a country where the resources allocated to ST\&I activities are proportionally lower than the resources allocated by OECD countries, the absence of clear priorities adherent to the local conditions might seriously harm the possible outcomes of the actions undertaken.

\section{Concluding remarks}

In this work, it has been argued that the wide acknowledgement of the association between innovation, economic and social development and the importance of innovation policies have formed a kind of "misty consensus" hardly contested in Brazil. However, the innovation policies adopted in the country lack an institutional framework to support their implementation, marking what was called a "messy dissensus". Thus, the reasons why the ST\&I policies failed to contribute more effectively to the increase of the Brazilian technological efforts have less to do with the policies themselves and more to do with their detachment from the institutional framework used to implement them, as the "messy dissensus" emerges at the moment these policies are put in march. To support that argument, it was shown that: 
- The institutional framework is barely adherent to the perception of a systemic nature of the innovation process. Although formulated according to a systemic model of the innovation process, the policies strongly rely on instruments which have much more to do with the linear model.

- There are not enough incentives for bureaucrats in public institutions to allocate resources to the industrial sector because it is much more socially acceptable that the government should direct its resources to universities and public research centers.

- The institutional framework encourages the pulverization of resources and the consequent loss of focus, which may reduce the efficiency of the adopted policies. As bureaucrats rely on the approval of the "scientific community", they prefer to contemplate each researcher with a small amount of resources than to focus on a few strategic projects. As a result, innovation policies tend to be shaped by the demand and not by the focus on strategic areas and the projects tend to lack scale and continuity.

- In practice, bureaucrats tend to adopt models and priorities established for contexts which are different from the Brazilian reality. Bounded rationality, bureaucrats' need of legitimacy and high levels of uncertainty are the reasons why policy-makers tend to replicate models and priorities shaped in other contexts.

The update of the institutional framework used to implement the innovation policies in Brazil is, therefore, required to make these policies contribute more effectively to the increase of the country's technological efforts. This update involves the creation of new incentives for bureaucrats and public institutions to allocate resources to the industrial sector. These incentives may include lighter and less bureaucratic procedures to direct resources to firms along with the creation of severe punishments in cases of misuse of resources. Policy evaluation should also be enhanced to allow the institutional framework to be calibrated. Finally, to avoid the pulverization of resources and foster the establishment of priorities more adherent to the local reality, transparency and accountability procedures could be applied to the innovation policies adopted in the country.

\section{Notes}

1. The main features of those policies are described in Section 2 of this work.

2. Between 2001 and 2010, average GDP growth rate reached 3.68 per cent, higher than the averages of the previous decades (2.61 per cent in the 1990s and 1.57 per cent in the 1980s). Between 2011 and 2013, growth rates reached 2.96 per cent (relatively high for Brazilian standards in the past decades). However, in 2014, 2015 and 2016 growth rates were only $0.5,-3.77$ and -3.59 per cent.

3. "[...] it takes all the running you can do, to keep in the same place. If you want to get somewhere else, you must run at least twice as fast as that!"

4. Cavalcante and De Negri (2011) and Cavalcante (2014) analyze the relation between business enterprise $R \& D$ expenditures and industrial structure in Brazil and compare it to the more developed countries.

5. Treasury bills interest rates in Brazil at the end of 2015, 2016 and 2017 reached 14.25, 13.75 and 7.00 per cent, respectively. Even considering their downward trend and adjusting for inflation, those rates are very high, particularly when compared to the interest rates in several developed countries, which remained close to zero in the same period. Rates of return of innovation project require a spread over the risk-free capital costs. As a result, on several occasions, these projects are simply unfeasible in Brazil. 


\section{INMR}

15,4

\section{4}

6. The ratio exports plus imports as a per cent of GDP, which is a usual measure of trade openness, is very low in Brazil (below 27 per cent according to the World Bank Data). Despite the limitations of this indicator - especially in the case of larger economies - it reinforces the perception that Brazilian firms are not exposed to international competition very much.

7. Authors like Pinto and Feldmann (2016, p. 66) argue that "the governments do not foster a proper institutional environment for the emergence of innovation", but those authors do not focus on the institutional framework used to implement the innovation policies.

8. According to the Merriam-Webster's dictionary, the first known use of the word "dissensus" in English dates back to 1962 . We decided to use it (instead of the more commonly used "dissent") to establish a contrast between the "misty consensus" and the "messy dissensus".

9. The reference document for the linear model is Bush (1945). Viotti (2003) mentions the chain link model and the technological learning model, which would better describe innovation process in developing countries.

10. Authors like Balconi, Brusoni and Orsenigo (2010), however, complain about the caricaturizing of the linear model, which is frequently presented in papers that discuss the systemic model. In additions, Mazzoleni and Nelson (2005) claim that the importance of the knowledge produced in universities and research institutes in the economic development process of a country has become increasingly higher.

11. In Brazil, in order to follow the Frascati Manual (OECD, 2002), the former MCTI calculated the business enterprise R\&D expenditures as the sum of (i) private and state enterprises expenditures; (ii) other federal state enterprises expenditures; (iii) R\&D expenditures in graduate programs in private institutions.

\section{References}

Araújo, B.C., Pianto, D., De Negri, F., Cavalcante, L.R. and Alves, P. (2012), "Impactos dos fundos setoriais nas empresas", Revista Brasileira de Inovação, (n. esp.), Vol. 11, pp. 85-112.

Balconi, M., Brusoni, S. and Orsenigo, L. (2010), "In defense of the linear model: An essay", Research Policy, Vol. 39 No. 1, pp. 1-13.

Bush, V. (1945), “Science the Endless Frontier”, United States Government Printing Office, Washington, DC, 1945, available at: https://goo.gl/YWChcE

Cassiolato, J.E. and Lastres, H.M.M. (2008), Discussing innovation and development: Converging points between the Latin American school and the innovation systems perspective? Globelics Working Paper 08-02, 2008, available at: https://goo.gl/7Zjm7D. (accessed 9 March 2017).

Cavalcante, L.R. (2009), "Politicas de Ciência, Tecnologia e Inovação No Brasil: uma Análise Com Base Nos Indicadores Agregados (Texto Para Discussão, $N^{\circ} 1458$ )". Instituto de Pesquisa Econômica Aplicada (Ipea), Rio de Janeiro, RJ.

Cavalcante, L.R. (2014), "An analysis of the business enterprise research and development expenditures composition in Brazil", Revista Brasileira de Inovação, Vol. 13 No. 2, pp. 433-458.

Cavalcante, L.R. and De Negri, F. (2011), "Trajetória Recente Dos Indicadores de Inovação No Brasil (Texto Para Discussão, $N^{\circ}$ 1659)". Instituto de Pesquisa Econômica Aplicada (Ipea), Rio de Janeiro, RJ.

De Negri, F. (2012), "Elementos Para a análise da baixa inovatividade brasileira e o papel das políticas públicas", Revista Usp, No. 93, pp. 81-100.

De Negri, F. and Cavalcante, L.R. (2013), "Sistemas de inovação e infraestrutura de pesquisa: considerações sobre o caso brasileiro”, Radar: tecnologia, Produção e Comércio Exterior, Vol. 24, pp. 7-18.

De Negri, F., Alves, P., Kubota, L.C., Cavalcante, L.R. and Damasceno, E.C. (2009), "Perfil Das Empresas Integradas ao Sistema Federal de C,T\&I No Brasil e Aos Fundos Setoriais: uma Análise Exploratória [Mimeo]", Ipea, Brasília. 
Feldmann, P.R. (2009), “O atraso tecnológico da américa latina como decorrência de aspectos geográficos e de fatores microeconômicos interligados”, Economia e Sociedade, Vol. 18 No. 1, pp. 119-139.

Freeman, C. (1987), “Technology Policy and Economic Performance: lessons from Japan”, Frances Pinter, London.

Lundvall, B. and Borrás, S. (2005), "Science, technology, and innovation policy", In Fagerberg, J., Mowery, D.C. and Nelson, R. (Eds). The Oxford Handbook of Innovation, The Oxford University Press, New York, NY.

Lundvall, B.Å. (1988), "Innovation as an interactive process: from user producer interaction to the national innovation systems", In G., Dosi, C., Freeman, R., Nelson, G., Silverberg and L., Soete (Eds), Technical Change and Economic Theory, Pinter Publishers, London.

Instituto de Estudos para o Desenvolvimento Industrial (IEDI) (2011), "Principais Tendências Nas Politicas Científicas, Tecnológicas e de Inovação Segundo a OCDE”, Carta IEDI, n. 452.

Johannessen, J.A. (2009), "A systemic approach to innovation: the interactive innovation model", Kybernetes, Vol. 38 Nos 1/2, pp. 158-176.

Keynes, J.M. (1937), "The general theory of employment”, The Quarterly Journal of Economics, Vol. 51 No. 2, pp. 209-223.

Kubota, L.C., Nogueira, M.O. and Milani, D.N. (2012), Avaliação Dos Fundos Setoriais: CT-Info. (Texto Para Discussão, $N^{\circ} 1752$ ), Instituto de Pesquisa Econômica Aplicada (Ipea), Brasília, DF.

Mazzoleni, R. and Nelson, R. (2005), "The Role of Research at Universities and Public Labs in Economic Catch-up”, Initiative for Policy Dialogue Working Paper.

Meyer, J. and Rowan, B. (1977), "Institutionalized organizations: formal structure as myth and ceremony", The American Journal of Sociology, Vol. 83 No. 2, pp. 340-363.

Morais, J.M. (2009), "Os fundos setoriais e as tendências recentes dos programas de subvenção econômica às empresas na FINEP. In IPEA”, Projeto Metodologia de Avaliação Dos Resultados de Conjuntos de Projetos Apoiados Por Fundos de Ciência, Tecnologia e Inovação (CT\&I). Relatório n. 4. Ipea.

Organisation for Economic Co-Operation and Development (OECD) (2002), "Frascati Manual: Proposed Standard Practices for Surveys on Research and Experimental Development”, OECD Publishing, Paris.

Organisation for Economic Co-Operation and Development (OECD) (2005), "Guidelines for Collecting and Interpreting Innovation Data", 3rd ed. OECD Publishing, Paris.

Pinto, K.E.F. and Feldmann, P.R. (2016), "Why Brazil doesn't innovate: a comparison among nations", Revista de Administração e Inovação, Vol. 13 No. 1, pp. 63-82.

Viotti, E.B. (2008), "Brasil: de política de ciência e tecnologia Para política de inovação? evolução e desafios das políticas brasileiras de ciência, tecnologia e inovação", In Centro de Gestão e Estudos Estratégico (CGEE). Avaliação de Politicas de Ciência, Tecnologia e Inovação: diálogos Entre Experiências Estrangeiras e Brasileira, CGEE, Brasília.

Viotti, E.B. (2003), "Fundamentos e evolução dos indicadores de CT\&I”, In E.B., Viotti and M.M., Macedo (Eds) (Orgs.). Indicadores de Ciência, Tecnologia e Inovação No Brasil, Unicamp, Campinas.

\section{Further reading}

Brazil (2018), "Brasil Maior: Inovar Para Competir. Competir Para Crescer (Plano, 2011-2014)”. N.d. (texto de referência).

\section{Corresponding author}

Luiz Ricardo Cavalcante can be contacted at: luiz.ricardo.teixeira.cavalcante@gmail.com

For instructions on how to order reprints of this article, please visit our website:

www.emeraldgrouppublishing.com/licensing/reprints.htm

Or contact us for further details: permissions@emeraldinsight.com 